\title{
Potassium-depolarization induces motility in isolated outer hair cells by an osmotic mechanism
}

\author{
Didier Dulon ${ }^{1}$, Jean Marie Aran ${ }^{1}$ and Jochen Schacht ${ }^{2}$ \\ ${ }^{1}$ Laboratoire d'A udiologie Expérimentale, INSERM Research Unit 229, Pellegrin Hospital, University of Bordeaux II, \\ Bordeaux, France; ${ }^{2}$ Kresge Hearing Research Institute, University of Michigan, Ann Arbor, Michigan, U.S.A.
}

(Received 20 August 1987; accepted 5 November 1987)

\begin{abstract}
Outer hair cells in vitro contract in response to various stimuli: electrical stimulation, $\mathbf{K}^{+}$-depolarization, elevation of intracellular calcium or osmotic changes of the extracellular medium. The characteristics of motile responses induced by $\mathrm{K}^{+}$-depolarization, osmotic changes, and calcium injection were compared in this study in order to delineate the underlying mechanisms. Slow shape changes in outer hair cells were induced by changes of the osmolality or the $\mathrm{K}^{+} / \mathrm{Na}^{+}$-ratio of the bathing medium, or by intracellular injections of calcium. $\mathrm{K}^{+}$- and osmotically induced contractions of isolated outer hair cells had identical morphological features and the same rate $(50-200 \mathrm{~nm} / \mathrm{s})$ and amplitude (up to $>10 \%$ of original length) of shortening. The shortening of the cells was linearly related to an increase in volume in both cases. In contrast, the active contraction induced by $\mathrm{Ca}^{2+} / \mathrm{ATP}$ exhibited a somewhat faster rate and no increase in volume. Furthermore, the $\mathrm{K}^{+}$-induced contractions in outer hair cells, unlike those reported in smooth muscle cells, were unaffected by the removal of external $\mathrm{Ca}^{2+}$ (i.e. medium without $\mathrm{Ca}^{2+} / \mathrm{Mg}^{2+}$ and supplemented with 1 mM EGTA) or the presence of $\mathrm{D} 600$, an inhibitor of the $\mathrm{Ca}^{2+}$ inward current. The results strongly suggest that $\mathrm{K}^{+}$induces shape changes of outer hair cells via osmotic forces and that intracellular calcium mediates contractions by a different mechanism.
\end{abstract}

Outer hair cell in vitro; Motility; Potassium; Osmolarity; Calcium

\section{Introduction}

Motile responses of isolated outer hair cells have been observed under various conditions in vitro. They can be elicited by extracellular stimuli such as potassium depolarization (Zenner et al., 1985), electric stimulation (Brownell, 1984; Brownell et al., 1985), and changes of osmolarity (Dulon et al., 1987) or by the intracellular action of $\mathrm{Ca}^{2+}$ and ATP (Zenner et al., 1986; Flock et al., 1986). While a role for the motility of hair cells in the control of cochlear micromechanics has been postulated (Neely and Kim, 1986), its physiological significance remains to be established. Knowledge of the underlying molecular mechanisms would aid considerably in understanding

Correspondence to: Dr. Jochen Schacht, Kresge Hearing Rescarch Institute, University of Michigan, Ann Arbor, MI 48109, U.S.A. these phenomena and in elucidating how they contribute to the physiology and pathology of the outer hair cells.

Two models have so far been postulated for the shape changes of outer hair cells observed in vitro: (1) a fast mechanism based on electroosmotic (Kachar et al., 1986) or electrostrictive (Ashmore, 1987) forces and (2) a slow muscle-like mechanism which might be mediated by contractile proteins and which requires $\mathrm{Ca}^{2+}$ and ATP (Zenner et al., 1986; Flock, 1986; Flock et al., 1986). An infracuticular actin network has indeed been demonstrated in outer hair cells (Zenner, 1986) and the laminated cisternae lining the cytoplasmic membrane of the lateral walls of the outer hair cells (Saito, 1983) have been suggested to be a calcium sequestering structure similar to the tubular network of the sarcomere (Flock et al., 1986) or the structure regulating intracellular hydrostatic pressure (Brownell, 1984; Kachar et al., 1986).

The mechanisms underlying both potassium- 
and electrically-induced contractions have not been elucidated and the aim of the present study was to investigate $\mathrm{K}^{+}$-induced contractions of outer hair cells in vitro. In particular, our previous finding of reversible osmotic influences on hair cells (Dulon et al., 1987) prompted us to investigate, in detail, the relationship between $\mathrm{K}^{+}-$and osmotically-induced motility and to compare them to the active contraction induced by intracellular injection of calcium and ATP.

\section{Methods}

Pigmented guinea pigs (280-340 g) were decapitated and the temporal bones quickly excised. The bullae and the bony walls of the cochleae were immediately opened and the upper turns of the organ of Corti removed. These were kept in Hank's balanced salt solution (HBSS) without $\mathrm{NaHCO}_{3}$ and buffered to $\mathrm{pH} 7.4$ with $5 \mathrm{mM}$ sodium HEPES. The solution was then adjusted to $300 \mathrm{mOsm}$ with $\mathrm{NaCl}$. After collagenase treatment $(0.1 \mathrm{mg} / \mathrm{ml} \mathrm{HBSS}$ for $15 \mathrm{~min}$ ), the tissues were placed in HBSS supplemented with $5 \%$ fetal calf serum and outer hair cells were isolated microsurgically as described previously (Zenner et al., 1985; Zajic and Schacht, 1987). Hair cells with cytoplasmic granulations, high position of the nucleus, swelling or other indications of deterioration (Zajic and Schacht, 1987) were excluded from the study.

For the experiments, hair cells were transferred into $50 \mu 1$ of HBSS on a microscopic cover slip and observed with an inverted microscope at high magnification in oil immersion (objective $\times 100$ ). The cells were continuously superfused with HBSS at a rate of $50 \mu \mathrm{l} / \mathrm{min}$ by means of a peristaltic pump (MS 4/8, Ismatic, Zurich, Switzerland). Cells changing their shape or morphological appearance during an initial $10 \mathrm{~min}$ "stabilizing period' were excluded from further observation. For the osmotic experiments, the osmolality of the HBSS was lowered with water or increased by addition of $\mathrm{NaCl}$. For the potassium experiments, the superfusing medium was a modified Hank's solution containing $100 \mathrm{mM} \mathrm{KCl}$ and adjusted with $\mathrm{NaCl}$ to $300 \mathrm{mOsm}$ (final $\left[\mathrm{Na}^{+}\right]=40 \mathrm{mM}$ ). For injections, micro-capillaries (resistances, 30-40
$\mathrm{M} \Omega$ ) were filled with $10 \mathrm{mM} \mathrm{CaCl}, 200 \mu \mathrm{M}$ ATP, $10 \mathrm{mM}$ Hepes, pH 7.2, $0.1 \mathrm{M} \mathrm{KCl}, 1 \%$ glycerol; osmolality $300 \mathrm{mOsm}$ ) and fixed to a stepping micromanipulator (Leitz) for the impalement of hair cells. Solutions for control injections were without calcium and with $1 \mathrm{mM}$ EGTA. The osmolality of the solutions was measured before and during the experiments with a micro-osmometer (Roebling, Berlin, F.R.G.).

The morphology of the cells was continuously monitored via a video camera system attached to the inverted microscope (Fluovert, Leitz, Wetzlar, F.R.G.) and the images were recorded for analysis with a U-matic video cassette recorder (VO-5800 PS, Sony Corporation, Japan) or with a film camera (Wild Photoautomat MPS 45). Film records, at a final magnification of $2500 \times$ were analyzed to determine the dimensions of the outer hair cells. In order to obtain cell volume from the two-dimensional images, the cells were assumed to be a cylinder and the volume was calculated from the diameter and length of the entire cells. The optical resolution was $0.4 \mu \mathrm{m}$.

\section{Results}

When subjected to a change of the osmolality in the external medium, outer hair cells responded with a rapid change in shape consistent with previous observations (Dulon et al., 1987). In decreasing osmolality, the cells shortened within seconds (Fig. 1a and b) and conversely, enlongated beyond their normal length upon exposure to hyperosmotic HBSS (not shown). The magnitude of length change was directly related to the difference in osmolality. It ranged from a $2.4 \pm 1.2 \%$ $(n=5)$ length change for a $3.3 \%$ change of osmolarity to $11.3 \pm 2.2 \%(n=29)$ for a $10 \%$ difference in osmolality (Fig. 2a). The cells exhibited an intact morphology for approximately $15 \mathrm{~min}$ at osmolalities between 280 and 330 mosmolal and returned to their initial length when re-exposed to iso-osmotic HBSS. Several cycles (up to five tested) of shape changes could be sustained by the hair cells without apparent degeneration. Prolonged exposure to hypo- or hyperosmolality, however, resulted in irreversible shortening, granulation of the cytoplasm, rounding and eventual destruction of the cells. Identical shape changes occurred in 


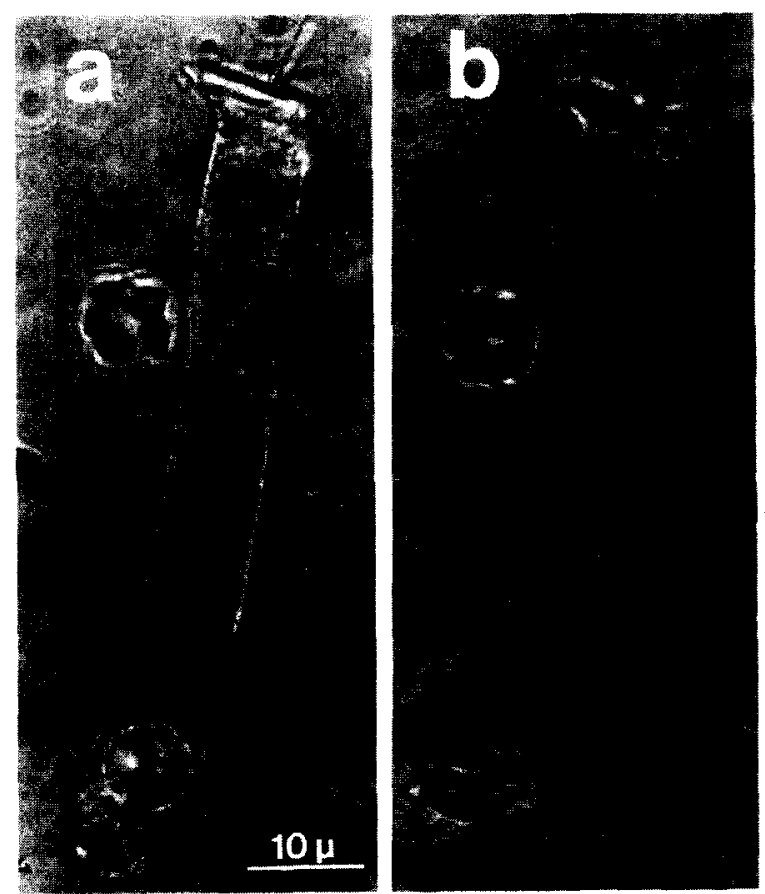

Fig. 1. Isolated outer hair cell shortening under osmotic variation. (a) in HBSS of $300 \mathrm{mOsm}$; (b) after 2 min of superfusion with HBSS of 280 mOsm.

HBSS without $\mathrm{Ca}^{2+} / \mathrm{Mg}^{2+}$ and supplemented with $1 \mathrm{mM}$ EGTA.

Superfusion of outer hair cells with a high $\left[\mathrm{K}^{+}\right]$ medium led to a marked longitudinal 'contraction' (Fig. 3a and b) as previously described by Goldstein and Mizukoshi (1967) and by Zenner et al. (1985). As with the osmotic changes, the shortening was reversible when the cells were re-exposed to a normal Hank's solution unless a prolonged exposure to $\mathrm{K}^{+}$(approximately $5 \mathrm{~min}$ ) had taken place. The contractile response was dependent on the $\left[\mathrm{K}^{\dagger}\right]$ in the superfusing medium (Fig. 2b) and the reductions in cell length ranged from $2.4 \% \pm$ $0.9(n=7)$ for $50 \mathrm{mM} \mathrm{K}{ }^{+}$to $9.4 \% \pm 1.2(n=7)$ for $140 \mathrm{mM} \mathrm{K}^{+}$. The rate of shortening was also dependent on the $\mathrm{K}^{+}$concentration, ranging from $50 \mathrm{~nm} / \mathrm{s}$ to $200 \mathrm{~nm} / \mathrm{s}$ for these concentrations.

As with the osmotically induced contraction, the $\mathrm{K}^{+}$-induced shortening was not dependent on the presence of calcium in the outside medium. Removal of external $\mathrm{Ca}^{2+}$ and the additional presence of EGTA $(1 \mathrm{mM})$ neither affected the ampli- tude nor the rate of contraction (Table I). Moreover, the addition of D600 (methoxy verapamil, 50 $\mu \mathrm{M})$ an inhibitor of the calcium inward current (Fleckenstein, 1977) did not abolish the $\mathrm{K}^{+}$-induced contraction. Valinomycin, a $\mathrm{K}^{+}$-ionophore which would collapse the transmembrane $\mathrm{K}^{+}$. gradient did not induce a change in hair cell length $(0.1 \pm 0.4 \%)$ nor did its presence alter the $\mathrm{K}^{+}$-induced contractile response. Likewise, the application of oubain, an inhibitor of the $\mathrm{Na}^{+} / \mathrm{K}^{+}$-ATPase, neither affected the length of the cells $(0.9 \pm 1.2 \%$ change after $5 \mathrm{~min})$ nor their response to $\mathrm{K}^{+}$. Relaxation of hair cells to near control length upon return to normal $\mathrm{K}^{+}$concentration was also observed in a medium depleted in calcium (EGTA, $1 \mathrm{mM}$ ) in contrast to the finding of Zenner (Zenner et al., 1985) who reported that external $\mathrm{Ca}^{2+}$ was essential for relaxation.

Several structural changes accompanied both the $\mathrm{K}^{+}$- and the osmotically induced contractions. An increase of volume was always associated with the shortening of the cells (Fig. 4) and a return to the original volume occurred upon relaxation. A downward deflection of the cuticular plate was evident in agreement with previous reports (Zenner et al., 1986). Such a movement also occurred in the $\mathrm{K}^{+}$-induced contraction in media depleted of $\mathrm{Ca}^{2+}$ (EGTA, $1 \mathrm{mM}$ ).

Calcium-induced contractions were evoked by passive injection. In this technique, less disruptive to the cell than stripping its membrane with detergents, the intracellular concentration of calcium

\section{TABLE I}

\section{PARAMETERS OF $\left[\mathrm{K}^{+}\right]$-INDUCED MOTILITY}

\begin{tabular}{|c|c|c|c|}
\hline Condition & $\begin{array}{l}\text { Decrease } \\
\text { in length } \\
(\%)\end{array}$ & $\begin{array}{l}\text { Increase } \\
\text { in volume } \\
(\%)\end{array}$ & $\begin{array}{l}\text { Relaxation ( } \% \text { of } \\
\text { original length) }\end{array}$ \\
\hline Control & $6.0 \pm 0.8$ & $12.2 \pm 2.8$ & $98.1 \pm 1.1$ \\
\hline $\begin{array}{l}-\mathrm{Ca}^{2+} / \mathrm{Mg}^{2+} \\
+ \text { EGTA } 1 \mathrm{mM}\end{array}$ & $7.2 \pm 3.5$ & $14.5 \pm 4.0$ & $96.5 \pm 2.1$ \\
\hline$+\mathrm{D} 60050 \mu \mathrm{M}$ & $5.7 \pm 0.8$ & $14.5 \pm 5.3$ & $97.5 \pm 0.9$ \\
\hline Valinomycin $25 \mu \mathrm{M}$ & $4.0 \pm 1.1$ & $11.4 \pm 5.8$ & $98.0 \pm 1.4$ \\
\hline Ouabain, $20 \mu \mathrm{M}$ & $5.9 \pm 1.3$ & $12.2 \pm 2.5$ & $97.4 \pm 1.3$ \\
\hline
\end{tabular}

Hair cells were isolated and treated as described in Methods. Motility was induced by $100 \mathrm{mM} \mathrm{KCl} ; n=5$ or 6 for each condition. Values are means \pm S.D. 

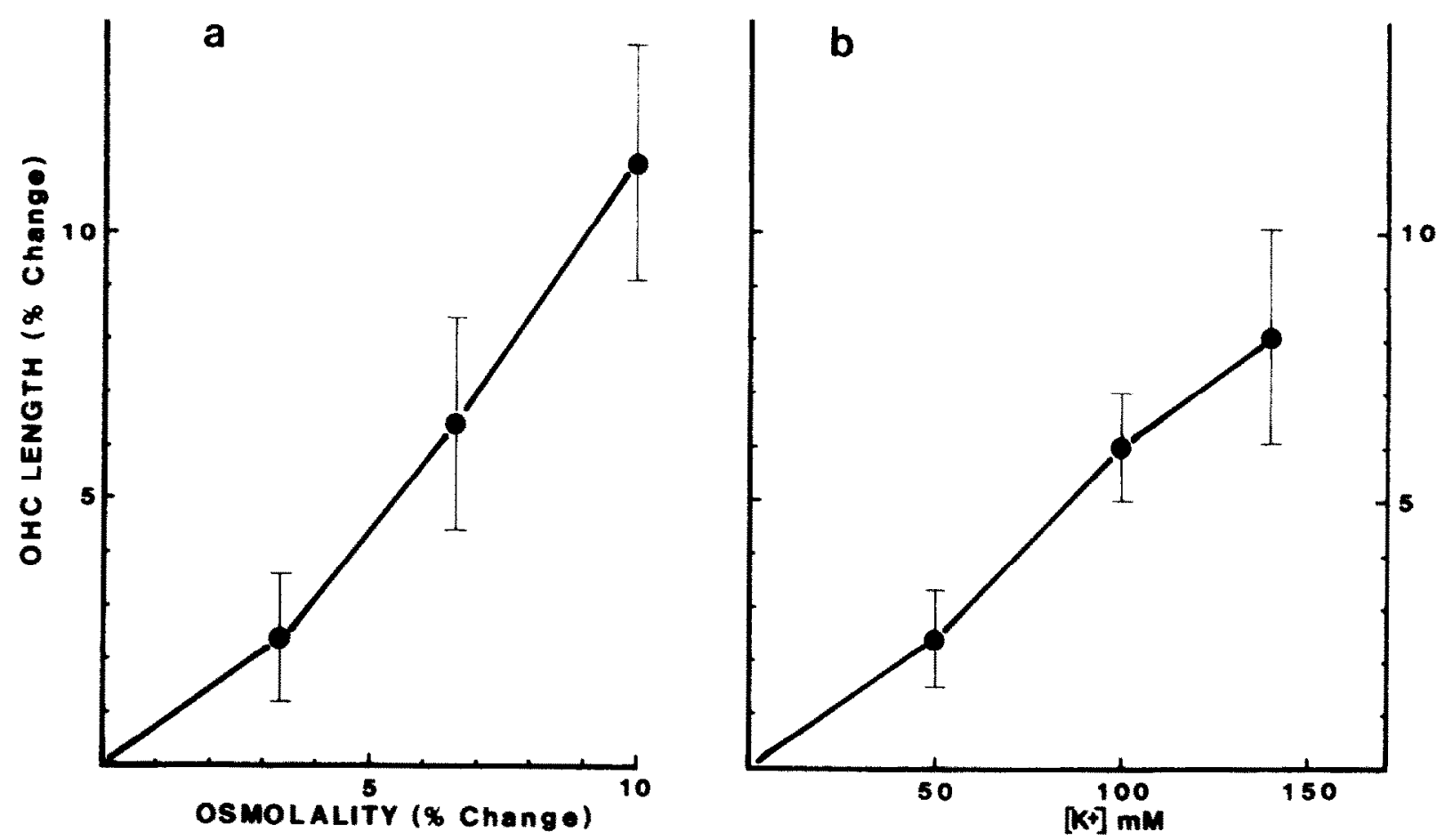

Fig. 2. (a) Magnitude of length change related to the difference in osmolality in the external medium. The values are means of 5 to 29 cells and the vertical bars represent the standard deviations. (b) Magnitude of length change related to the concentration of $\left[\mathrm{K}^{+}\right]$ present in the modified medium. The values are means of 7 cells each and the vertical bars represent the standard deviation.

was raised by diffusion of an appropriate solution from a micro-capillary. The rate of diffusion was evaluated with a solution containing the fluorescent probe fluoresceine isothiocyanate $(1 \mathrm{mM})$. Ten to $15 \mathrm{~s}$ after the impalement of the cell,

\section{TABLE II}

COMPARATIVE PARAMETERS OF OSMOTICALLY, $\left[\mathrm{K}^{+}\right]$, AND $\mathrm{Ca}^{2+} /$ ATP-INDUCED MOTILITY

\begin{tabular}{llll}
\hline Treatment & $\begin{array}{l}\text { Decrease in } \\
\text { length } \\
(\%)\end{array}$ & $\begin{array}{l}\text { Increase in } \\
\text { volume } \\
(\%)\end{array}$ & $\begin{array}{l}\text { Rate of } \\
\text { contraction } \\
(\mathrm{nm} / \mathrm{s})\end{array}$ \\
\hline $\begin{array}{l}\text { Osmotic Change } \\
{\left[\mathrm{K}^{+}\right] \text {-depolari- }} \\
\begin{array}{c}\text { zation } \\
\mathrm{Ca}^{2+} / \mathrm{ATP}\end{array}\end{array}$ & $\begin{array}{l}6.8 \pm 1.8 \\
6.0 \pm 0.8\end{array}$ & $14.8 \pm 5.0$ & $170 \pm 20$ \\
\hline
\end{tabular}

Hair cells were isolated and treated as described in "Methods". Effects of osmotic changes ( 300 to $280 \mathrm{mOsm})$ and $\left[\mathrm{K}^{+}\right](100$ $\mathrm{mM}$ ) were measured after $1 \mathrm{~min}$ superfusion; effects of calcium, 15-60 $\mathrm{s}$ after the empalement of the cell.

Values are means \pm S.D.; $n=10$ (osmotic), $5\left[\mathrm{~K}^{+}\right]$and 12 $\left(\mathrm{Ca}^{2+} / \mathrm{ATP}\right)$. intense fluorescence could be seen in the entire cytoplasm. Within this time the cell underwent a fast longitudinal contraction if $\mathrm{Ca}^{2+}$ and ATP were present in the injection pipette (Fig. 5a and b). Under the conditions of our study the $\mathrm{Ca}^{2+} /$ ATP-induced contraction showed a similar magnitude but a faster rate than those induced by $\mathrm{K}^{+}$and osmolality, but most importantly, no change in volume (Table II). A downward movement of the cuticular plate also occurred during the $\mathrm{Ca}^{2+}$-induced contraction.

\section{Discussion}

The present study confirms the existence of at least two different mechanisms underlying the slow motile responses of outer hair cells and suggests that $\mathrm{K}^{+}$-induced 'contractions' are identical to those observed in response to osmotic changes. The osmotically- and $\mathrm{K}^{+}$-induced contractions were identical in all parameters tested: they exhibited similar rates and amplitude of shortening, 

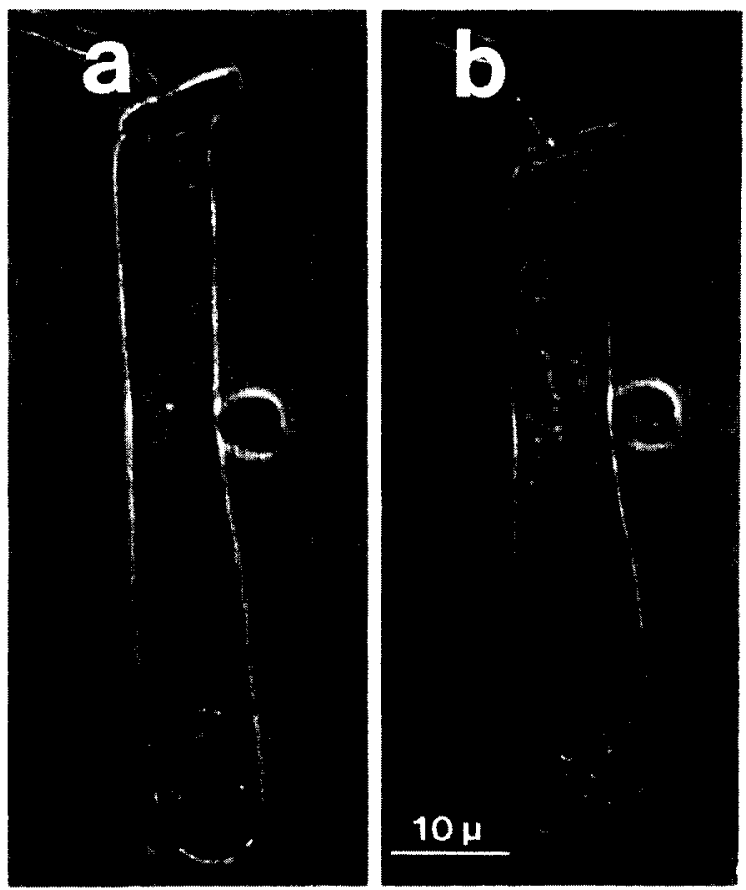

Fig. 3. Isolated outer hair cell shortening upon exposure to high $\left[\mathrm{K}^{+}\right]$. Hair cells were isolated and treated as described in Methods. (a) in HBSS of $300 \mathrm{mOsm}$; (b) after $2 \mathrm{~min}$ of superfusion with modified HBSS $\left(\mathrm{K}^{+}, 100 \mathrm{mM} ; 300 \mathrm{mOsm}\right)$.

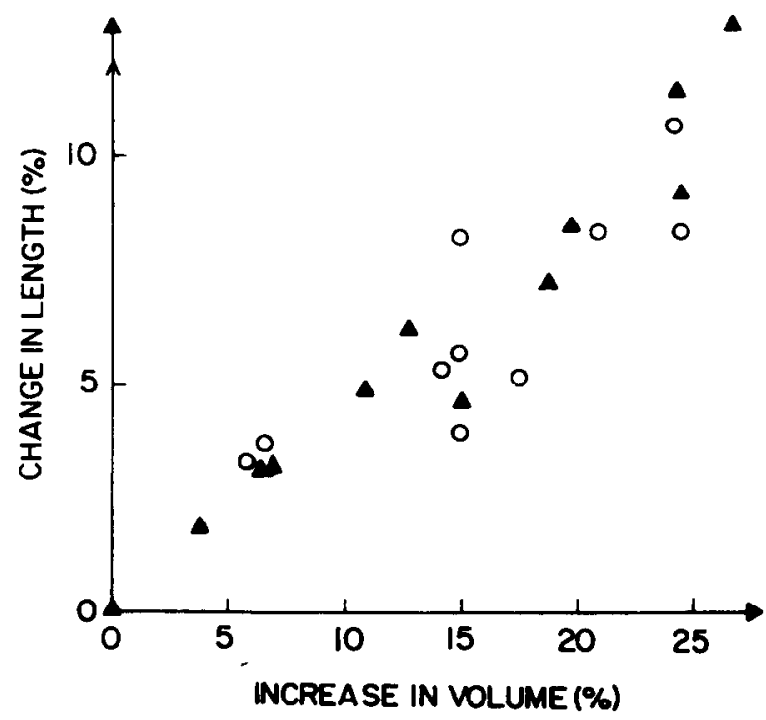

Fig. 4. Correlation between change in length and increase in volume after $\left[\mathrm{K}^{+}\right](\Delta)$ and osmotic $(O)$ stimulation. The hair cells were superfused with modified HBSS ( 280 or 290 mOsm; or $100 \mathrm{mM} \mathrm{K}^{+}$at $300 \mathrm{mOsm}$ ). Changes in length and volume were measured as described in Methods at various times of incubation (1-5 min). and an independence of extracellular calcium for both the contractions and the relaxation, and the shortening under both conditions was accompanied by an increase of the volume of the cells. The relation of length to volume changes was linear and identical for the two conditions regardless of the magnitude of length change (Fig. 4). Also, all morphological features of $\mathrm{K}^{+}$-induced contractions described previously (Zenner, 1986) such as movement of the cuticular plate relative to the long axis of the cell, are evident in the osmotically induced contractions.

The suggestion that the $\mathrm{K}^{+}$-induced motility in outer hair cells is based on an osmotic mechanism and different from the active, calcium-mediated contraction is reinforced by the fact that the contraction induced by $\mathrm{Ca}^{2+} / \mathrm{ATP}$ injections occurred without change in volume. In addition, the $\mathrm{K}^{+}$-induced contractions of outer hair cells are significantly different from those of smooth muscle cells which have been correlated with a decrease in cellular volume (Fay and de Pise, 1973; Amedeé et al., 1986). Also, removal of the external $\mathrm{Ca}^{2+}$ (presence of $1 \mathrm{mM}$ EGTA) or the presence of D600 (1-50 $\mu \mathrm{M})$ did not suppress the $\mathrm{K}^{+}$-induced contraction as has been shown for smooth muscle cells (Amedeé et al., 1986). Likewise, relaxation occurred in the absence of calcium. These differences suggest that $\mathrm{K}^{+}$-induced motility of outer hair cells is independent of contractile proteins. Whether the osmotic mechanism suggested here is related to an electroosmotic process postulated for electrically-induced motility (Kachar et al., 1986) remains to be established. It is interesting in this context that Ashmore (1987) recently ruled out both actin/myosin interactions and water movement as a mechanism of voltage-driven fast hair cell movement.

The question then arises as to which ion is responsible for the osmotic gradient in $\mathrm{K}^{+}$-depolarization. From our preliminary experiments, calcium seems unlikely on the basis of the results in the absence of calcium (presence of EGTA) and the addition of the calcium channel, blocking agent, methoxy verapamil. $\mathrm{K}^{+}$may probably also be excluded as the responsible ion. The $\mathrm{K}^{+}$-gradient between the cells and the medium should be opposite to a possible influx, even at the elevated extracellular concentrations. Furthermore, at- 

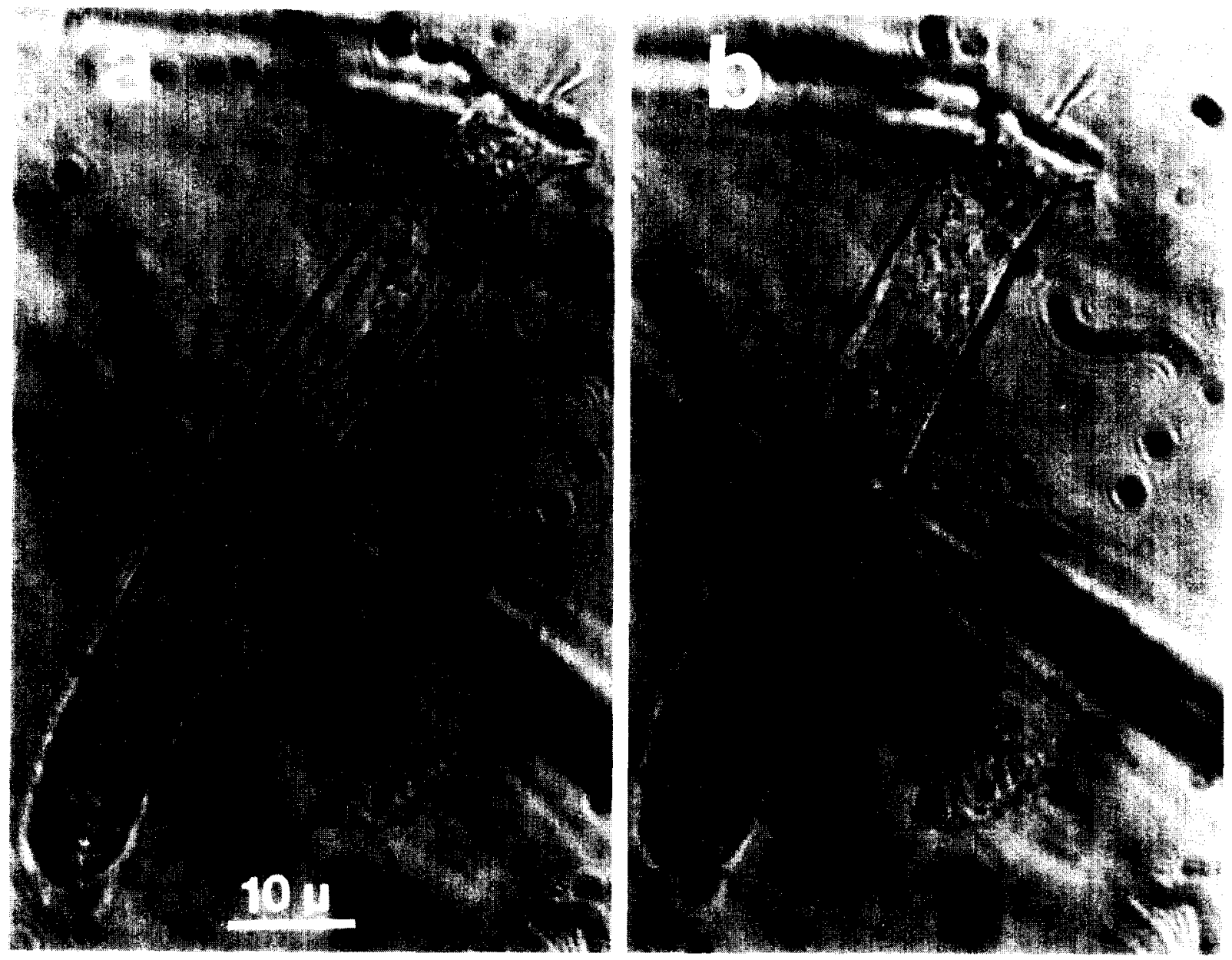

Fig. 5. Contraction in response to calcium/ATP. Hair cells were isolated and treated as described in "Methods". a) Before and b) 15 s after injection of $\mathrm{Ca}^{2+} / \mathrm{ATP}$

tempted manipulations of the $\mathrm{K}^{+}$gradient with the $\mathrm{K}^{+}$-ionophore valinomycin and the $\mathrm{Na}^{+} / \mathrm{K}^{+}$ATPase blocker ouabain, did not affect the contractions. Thus, the question of the ionic species including the osmotic swelling presently remains open.

The $\mathrm{K}^{+}$-induced contractions are an intriguing phenomenon whose significance is speculative. They appear unrelated to the fast voltage-dependent hair cell response which may constitute the active component of basilar membrane micromechanics and which is not based on water movement across the cell membrane (Ashmore, 1987). They also differ from the slow $\mathrm{Ca}^{2+}$-dependent muscle-like response which may be an adaptive mechanism under control of the efferent neurotransmitter possibly mediated by the phosphoinositide second messenger system (Schacht and Zenner, 1986). Thus, it seems difficult to place this phenomenon into the normal physiology of the cochlea. However, aside from the possibility of being an in vitro artifact, $\left[\mathrm{K}^{+}\right]$-induced shape changes of outer hair cells together with the mechanistically similar osmotically induced changes could play an important role in transiently altering cochlear mechanics under pathological conditions such as acoustic trauma or Menière's disease (Zenner et al., 1985; Dulon et al., 1987). 


\section{Acknowledgement}

This research was supported by a grant from the Deafness Research Foundation, research grant NS-05785 from the National Institutes of Health and an INSERM Fellowship to Jochen Schacht.

\section{References}

Amedeé, T., Mironneau, C. and Mironneau J. (1986) Isolation and contractile responses of single pregnant rat myometrial cells in short-term primary culture and the effects of pharmacological and electrical stimuli. Br. J. Pharmac. 88, 873-880.

Ashmore, J.F. (1987) A fast motile response in guinea pig outer hair cells: the cellular basic of the cochlear amplifier. J. Physiol. 388, 323-347.

Brownell, W.E. (1984) Microscopic observation of cochlear hair cell motility. Scan. Electron. Microsc. 3, 1401-1406.

Brownell, W.E., Bader, C.R., Bertrand, D. and de Ribaupierre, Y. (1985) Evoked mechanical responses of isolated cochlear outer hair cells. Science 227, 194-196.

Dulon, D., Aran, J.M. and Schacht, J. (1987) Osmotically induced motility of outer hair cells: Implication for Menière's disease. Arch. Otorhinolaryngol. 244, 104-107.

Fay, F.S. and DePise, C.M. (1973) Contraction of isolated smooth-muscle cells - structural changes. Proc. Nat. Acad. Sci. U.S.A. 70, 641-645.

Fleckenstein, A. (1977) Specific pharmacology of calcium in myocardium, cardiac pacemakers, and vascular smoothmuscle. Ann. Rev. Pharmac. Toxicol. 17, 149-166.

Flock, A. (1986) Mechanical properties of hair cells. Hear. Res. $22,80$.

Flock, A., Flock, B. and Ulfendahl, M. (1986) Mechanisms of movement in outer hair cells and possible structural basis. Arch. Otorhinolaryngol. 243, 83-90.

Goldstein, A.J. and Mizukoshi, O. (1967) Separation of the organ of Corti into its components. Ann. Otol. Rhinol. Laryngol. 76, 414-426.

Kachar, B., Brownell, W.E., Altschuler, R. and Fex, J. (1986) Electrokinetic shape changes of cochlear outer hair cells. Nature 322, 365-368.

Neely, S.T. and Kim, D.O. (1986) A model for active elements in cochlear biomechanics. J. Acoust. Soc. Am. 79, 1472-1480.

Saito, K. (1983) Fine structure of the sensory epithelium of guinea pig organ of Corti: subsurface cisterna and lamellar bodies in the vuler hair cells. Cell. Tiss. Res. 229: 467-481.

Schacht, J. and Zenner, H.P. (1986) The phosphoinositide cascade in isolated outer hair cells: possible role as second messenger for motile responses. Hear. Res. 22, 94.

Zajic, G. and Schacht, J. (1987) Comparison of isolated outer hair cells from five mammalian species. Hear. Res. 26, 249-256.

Zenner, H.P. (1980) Cytoskeletal and muscle-like elements in cochlear hair cells. Arch. Oto-Rhino-Laryngol. 230, 82-92.

Zenner, H.P. (1986) Motile responses in outer hair cells. Hear. Res. 22, 83-90.

Zenner, H.P., Zimmermann, U. and Schmitt, U. (1985) Reversible contraction of isolated mammalian cochlea hair cells. Hear. Res. 18, 127-133. 